\title{
PENGARUH LOKASI OTOT DAN BAHAN PENGISI TERHADAP KUALITAS KIMIA DAN ORGANOLEPTIK SOSIS SAPI
}

\author{
Hasmiarni Aris ${ }^{1)}$, Harapin Hafid ${ }^{2)}$ dan Deki Zulkarnain ${ }^{2)}$ \\ ${ }^{1)}$ Alumnus Fakultas Peternakan Universitas Halu Oleo \\ ${ }^{2)}$ Fakultas Peternakan Universitas Halu Oleo \\ "e-mail : Harapin.hafid@yahoo.co.id
}

\begin{abstract}
ABSTRAK
Tujuan penelitian ini adalah mengkaji pengaruh lokasi otot dan bahan pengisi terhadap kualitas kimia sosis sapi. Penelitian ini menggunakan Rancangan Acak Lengkap (RAL) dengan pola faktorial. Faktor pertama (A) adalah BF (A1), LD (A2) dan PP (A3). Faktor kedua (B) adalah 10\% (B1), 20\% (B2) dan $30 \%$ (B3). Masing-masing perlakuan diulang sebanyak tiga kali. Hasil penelitian menunjukan, interaksi lokasi otot dengan bahan pengisi berpengaruh yang sangat nyata $(p<0,01)$ terhadap kadar protein, kadar lemak, kadar air, kadar abu dan berpengaruh nyata $(p<0,05)$ terhadap kadar karbohidrat tetapi tidak berpengaruh nyata $(p>0,05)$ terhadap kualitas organoleptik. Secara mandiri lokasi otot berpengaruh sangat nyata $(p<0,01)$ terhadap kadar protein, kadar lemak, kadar air, kadar abu, warna, tekstur dan berpengaruh nyata $(p<0,05)$ terhadap kadar karbohidrat, keempukan dan aroma tetapi tidak berpengaruh nyata $(p>0,05)$ terhadap citarasa sosis. Secara mandiri bahan pengisi memberikan pengaruh sangat nyata $(p<0,01)$ terhadap kadar protein, kadar lemak, kadar air, kadar abu, keempukan dan berpengaruh nyata $(p<0,05)$ terhadap kadar karbohidrat dan aroma tetapi tidak berpengaruh nyata $(p>0,05)$ terhadap warna dan citarasa sosis sapi. Dapat disimpulkan interaksi lokasi otot dan bahan pengisi pada kualitas kimia, perlakuan pectoralis profundus (PP) dengan bahan pengisi $10 \%$, baik digunakan dalam pembuatan sosis karena mengandung lemak yang rendah dan protein yang tinggi serta kualitas organoleptik yaitu longissimus dorsi (LD) dengan bahan pengisi $10 \%$ dilihat dari tingkat kesukaan panelis.
\end{abstract}

Kata kunci: $\quad$ Lokasi otot, Pengisi, Organoleptik, Sosis.

\begin{abstract}
The objective of this research was to investigate the effect of tendon location and filler with chemistry quality of sausage. These research uses Complete Random Plan (CRP) with factorial pattern. First factor (A) is BF (A1), LD (A2) and PP (A3). Seconf factor (B) is 10\% (B1), 20\% (B2) dan $30 \%$ (B3). Each treatment is repeated three times. Variable that is monitored is the chemistry quality and organoleptic. The result of the research shows, the tendon located interaction with filler gives a strong significant effect $(p<0,01)$ on the protein, fat, ash standard and so does the carbohydrate standard $(p<0,05)$ but give unsignificant effect on the quality of organoleptic. Independently, the tendon location gives significant effect $(p<0,01)$ on the protein, fat, ash, color, texture standard, and so does carbohydrate, tenderness, and aroma standard as $(p<0,05)$ but gives unsignificant effect on sausage taste $(p>0,05)$. Independently, filler gives strong significant effect $(p<0,01)$ on the standard of protein, fat, water, tenderness, and significant effect on the standard of carbohydrate and aroma but give unsignificant effect on the color and taste of the sausage $(p>0,05)$. It can be concluded that tendon located interaction and filler in chemistry quality, pectoralis profundus (PP) treatment with 10 $\%$ of filler, is good to be used in the making of sausage because has low fat and high protein and also quality of organoleptic, longissimus dorsi (LD) with $10 \%$ of filler that is seen from panelist favorite levels.
\end{abstract}

Key words: Tendon location, Filler, Organoleptic, Sausage

${ }^{*}$ Corresponding authors 


\section{PENDAHULUAN}

Kecukupan gizi sangat mempengaruhi kelangsungan hidup manusia tidak hanya untuk bertahan hidup tetapi juga untuk melakukan berbagai aktivitas. Mengingat peran gizi yang begitu penting, sebagai konsumen seyogyanya senantiasa mengutamakan dan memperhatikan kualitas dari makanan yang dikonsumsi.

Daging sapi dikenal sebagai salah satu bahan pangan yang bernilai gizi tinggi karena mengandung asam amino essensial yang lengkap. Komposisi kimia daging meliputi $19 \%$ protein, $5 \%$ lemak, $70 \%$ air, $3,5 \%$ zat-zat non protein dan 2,5\% mineral dan bahan-bahan lainnya (Forrest et al., 1975). Namun daging mempunyai sifat mudah rusak. Sehingga diperlukan pengolahan untuk mengurangi kerusakan daging pasca panen sekaligus memperoleh nilai tambah dari produk yang dihasilkan. Pengolahan daging bertujuan untuk memperpanjang masa simpan, memperbaiki sifat organoleptik, dan menambah variasi bentuk hasil olahan daging sehingga dapat menghemat waktu dan energi untuk persiapan daging sebelum dikonsumsi.

Salah satu cara pengolahan daging yang dikenal oleh masyarakat adalah sosis. Sosis merupakan produk emulsi daging yang ditambahkan bahan pengisi, bahan pengikat dan bumbu-bumbu untuk meningkatkan flavor dan daya terima. Sosis umumnya dibuat dari daging sapi, namun jenis daging lainnya seperti ayam dan kelinci dapat juga digunakan. Hasil produk olahan daging ini juga memiliki kualitas gizi yang sehat dan citarasa yang cukup tinggi, sehingga cukup menarik masyarakat.

Pemilihan daging dalam pembuatan sosis sangat penting karena jaringan atau organ ternak mengandung air, protein dan lemak dalam jumlah yang bervariasi. Daging dan hasil sisa jaringan ternak yang dapat digunakan dalam pembuatan sosis adalah daging dari otot skeletal, daging dari bagian kepala dan pipi (Effendi,
2009). Disamping pemilihan daging, untuk mendapatkan sosis yang kualitasnya baik maka diperlukan bahan pengisi berupa tepung terigu yang berkualitas pula. Tepung terigu mempunyai kemampuan untuk mengikat air, meningkatkan stabilitas emulsi, meningkatkan daya ikat air dan meningkatkan flavor proses pembuatan sosis. Oleh karena itu, perlu dilakukan penelitian mengenai tingkat persentase tepung terigu sebagai bahan pengisi terhadap lokasi otot yang berbeda dalam pembuatan sosis sapi agar diperoleh kualitas sosis daging sapi yang optimal.

\section{MATERI DAN METODE}

Penelitian ini dilaksanakan di Laboratorium Penelitian, Jurusan Peternakan, Fakultas Peternakan, Universitas Haluoleo, Kendari, pada bulan Oktober sampai Januari 2012. Bahan yang digunakan dalam penelitian ini terdiri dari bahan utama dan bahan tambahan. Bahan utama untuk adonan sosis adalah daging sapi prerigor dari 3 macam otot yaitu Biceps femoris (BF), Longissimus dorsi (LD) dan Pectoralis profundus (PP).diperoleh dari RPH Kota Kendari, sedangkan bahan tambahan yang digunakan terdiri dari, garam, es batu, merica, pala, bawang putih, minyak, susu skim bubuk serta bahan pengisi (tepung terigu) Adapun alat yang akan digunakan untuk membuat sosis antara lain pembuat adonan (food processor), lemari pendingin, timbangan digital, selongsong plastik. Peralatan dapur yang digunakan adalah pisau, sendok, pemanas listrik (hot plate), wadah plastik, piring, pengukus, serta alat-alat yang digunakan untuk analisis kimia dan uji organoleptik yaitu peralatan gelas (labu Kjeldahl, labu Soxhlet, kertas saring, pipet tetes, pipet volumetrik, gelas ukur, tabung reaksi, gelas piala, labu takar), oven, tanur listrik, desikator, timbangan analitik, cawan, penjepit cawan, pemanas listrik (hot plate), Texture Analyzer, pengepres hidraulik, inkubator dan cawan. 
Penelitian ini menggunakan Rancangan Acak Lengkap pola faktorial. Faktor pertama (A) adalah lokasi otot yang terdiri dari BF (A1), LD (A2) dan PP (A3). Faktor kedua (B) adalah bahan pengisi yang terdiri dari 10\% (B1), 20\% (B2) dan $30 \%$ (B3) dari bobot daging. Masingmasing perlakuan diulang tiga kali.

Variabel yang diamati kualitas kimia terdiri dari kadar protein, lemak, abu, air dan kadar karbohidrat. Kualitas organoleptik dikaukan dengan dengan cara uji hedonik untuk mengetahui tingkat kesukaan panelis terhadap produk sosis berdasarkan kriteria warna, aroma, cita rasa, keempukan, dan tekstur. Panelis yang digunakan sebanyak 15 orang panelis semi terlatih yakni Mahasiswa Universitas Haluoleo Kendari. Pengujian skoring dengan skor 1-5 (1 skor terendah dan 5 skor tertinggi).

Komposisi bahan baku pada proses pembuatan sosis sapi meliputi : daging 200 gr, bahan pengisi (tepung terigu) dengan persentase $10 \%$, 20\% dan $30 \%$ dari bobot daging susu skim 15 gram, minyak 5 gram, lemak 15 gram, garam 3,5 gram, bawang putih 2 gram, pala 0,2 gram, lada 05 gram dan es batu 40 gram.
Analisis data dilakukan secara sidik ragam menurut petunjuk Steel dan Torrie (1991). Apabila terdapat perbedaan pengaruh perlakuan terhadap peubah yang diamati, dilanjutkan dengan uji Beda Nyata Jujur (BNJ).

\section{HASIL DAN PEMBAHASAN \\ A. Kualitas Kimia Sosis Sapi}

Hasil analisis ragam menunjukan bahwa lokasi otot (faktor A) memberikan pengaruh mandiri yang sangat nyata $(p<0,01)$ terhadap kadar protein, kadar lemak, kadar air, kadar abu dan berpengaruh nyata $(p<0,05)$ terhadap kadar karbohidrat. Demikian halnya dengan bahan pengisi (faktor B) dan interaksi lokasi otot dan bahan pengisi memberikan pengaruh yang sangat nyata $(p<0,01)$ terhadap kadar protein, kadar lemak, kadar air, kadar abu dan berpengaruh nyata $(p<0,05)$ terhadap kadar karbohidrat.

\section{Pengaruh Interaksi Lokasi Otot dengan Bahan Pengisi}

Pengaruh interaksi antara lokasi otot dengan bahan pengisi terhadap kualitas kimia sosis sapi dapat dilihat pada Tabel 1.

Tabel 1. Rata-rata Interaksi Lokasi Otot dan bahan pengisi terhadap Kualitas Kimia Sosis Sapi

\begin{tabular}{lcccc}
\hline \multirow{2}{*}{ Peubah } & \multirow{2}{*}{ Lokasi Otot } & \multicolumn{3}{c}{ Bahan Pengisi } \\
\cline { 3 - 5 } & & $10 \%(\mathrm{~B} 1)$ & $20 \%(\mathrm{~B} 2)$ & $30 \%(\mathrm{~B} 3)$ \\
\hline \multirow{3}{*}{ Protein } & BF (A1) & $14,14 \pm 0,06^{\mathrm{e}}$ & $13,59 \pm 0,07^{\mathrm{f}}$ & $13,73 \pm 0,01^{\mathrm{g}}$ \\
& LD (A2) & $14,78 \pm 0,04^{\mathrm{c}}$ & $14,53 \pm 0,04^{\mathrm{d}}$ & $14,19 \pm 0,07^{\mathrm{e}}$ \\
& PP (A3) & $15,87 \pm 0,03^{\mathrm{a}}$ & $15,80 \pm 0,03^{\mathrm{a}}$ & $15,70 \pm 0,01^{\mathrm{b}}$ \\
\hline \multirow{3}{*}{ Lemak } & BF (A1) & $19,40 \pm 0,02^{\mathrm{d}}$ & $19,27 \pm 0,04^{\mathrm{d}}$ & $19,31 \pm 0,03^{\mathrm{d}}$ \\
& LD (A2) & $23,21 \pm 0,10^{\mathrm{a}}$ & $22,60 \pm 0,07^{\mathrm{b}}$ & $22,33 \pm 0,08^{\mathrm{c}}$ \\
& PP (A3) & $18,63 \pm 0,04^{\mathrm{e}}$ & $18,41 \pm 0,05^{\mathrm{f}}$ & $18,31 \pm 0,02^{\mathrm{f}}$ \\
\hline \multirow{3}{*}{ Air } & BF (A1) & $56,39 \pm 0,02^{\mathrm{b}}$ & $56,75 \pm 0,11^{\mathrm{a}}$ & $55,97 \pm 0,03^{\mathrm{d}}$ \\
& LD (A2) & $53,87 \pm 0,00^{\mathrm{f}}$ & $53,70 \pm 0,05^{\mathrm{g}}$ & $52,77 \pm 0,05^{\mathrm{h}}$ \\
& PP (A3) & $56,13 \pm 0,05^{\mathrm{c}}$ & $56,13 \pm 0,02^{\mathrm{c}}$ & $55,74 \pm 0,02^{\mathrm{e}}$ \\
\hline \multirow{3}{*}{ Abu } & BF (A1) & $2,19 \pm 0,01^{\mathrm{a}}$ & $1,96 \pm 0,03^{\mathrm{b}}$ & $1,87 \pm 0,01^{\mathrm{c}}$ \\
& LD (A2) & $1,76 \pm 0,01^{\mathrm{d}}$ & $1,78 \pm 0,00^{\mathrm{d}}$ & $1,84 \pm 0,01^{\mathrm{c}}$ \\
\hline \multirow{2}{*}{ Karbohidrat } & PP (A3) & $1,75 \pm 0,00^{\mathrm{d}}$ & $1,75 \pm 0,04^{\mathrm{d}}$ & $1,75 \pm 0,02^{\mathrm{d}}$ \\
& BF (A1) & $8,00 \pm 0,00^{\mathrm{a}}$ & $8,00 \pm 0,00^{\mathrm{a}}$ & $8,00 \pm 0,00^{\mathrm{a}}$ \\
& LD (A2) & $7,76 \pm 0,23^{\mathrm{b}}$ & $8,00 \pm 0,00^{\mathrm{a}}$ & $8,04 \pm 0,04^{\mathrm{a}}$ \\
& PP (A3) & $8,00 \pm 0,00^{\mathrm{a}}$ & $8,00 \pm 0,00^{\mathrm{a}}$ & $8,05 \pm 0,05^{\mathrm{a}}$ \\
\hline
\end{tabular}

- Notasi huruf yang berbeda ke arah baris dan kolom menunjukan berbeda sangat nyata pada taraf $(p<0,01)$

- Nilai dinyatakan dengan rerata \pm standar deviasi 
Uji lanjut BNJ menunjukan bahwa penggunaan Pectoralis profundus (PP) pada persentase $10 \%$ (A3B1) lebih tinggi daripada kombinasi perlakuan lainnya, terhadap kandungan protein sosis sapi yaitu $15,87 \%$. Secara umum rataan kadar protein pada setiap kombinasi perlakuan semakin menurun dengan peningkatan bahan pengisi (tepung terigu). Hal ini sesuai dengan pernyataan (Maharaja, 2008) yang menyatakan bahwa semakin tinggi jumlah bahan pengisi (tepung terigu) yang ditambahkan maka jumlah daging yang digunakan akan semakin sedikit, sehingga kadar protein akan semakin rendah pula karena daging merupakan sumber protein yang lebih dominan dibandingkan dari tepung.

Kadar lemak berdasarkan Uji lanjut BNJ menunjukan bahwa penggunaan Pectoralis profundus (PP) $10 \%$ berbeda nyata lebih baik dibandingkan kombinasi perlakuan lainnya, terhadap kandungan lemak sosis sapi yaitu 18,63\%. Menurut (Muchtadi., dkk, 2010), menyatakan bahwa dengan meningkatnya kandungan protein daging maka kandungan lemaknya akan menurun.

Berdasarkan uji lanjut BNJ menunjukan bahwa semua kombinasi perlakuan nampak adanya perbedaan yang sangat nyata. Rataan kadar air interaksi antara lokasi otot dan bahan pengisi cenderung menurun dengan peningkatan persentase tepung, tertinggi diperoleh pada perlakuan $\mathrm{BF} 20 \%$ yaitu $56,75 \%$ dan terendah pada LD $30 \%$ yaitu $52,77 \%$. Hal ini sesuai dengan pernyataan (Manullang dkk., 1995) yang menyatakan bahwa penurunan kadar air akibat interaksi pati dan protein sehingga air tidak dapat diikat secara sempurna karena ikatan hidrogen yang seharusnya mengikat air telah dipakai untuk interaksi pati dan protein daging. Dengan demikian semakin tinggi bahan pengisi (tepung terigu) yang digunakan maka massa tepung dalam sosis semakin besar dan kadar air sosis semakin menurun.

Pada uji BNJ menunjukan bahwa penggunaan Biceps femoris (BF) dengan bahan pengisi $10 \%$ berbeda nyata lebih baik daripada kombinasi perlakuan lainnya, terhadap kadar abu sosis sapi yaitu 2,19\%. Standar Nasional Indonesia (SNI) 01-3020-1995 merekomendasikan bahwa sosis sapi memiliki kadar abu maksimum 3\% berat basah.

Berdasarkan uji lanjut BNJ menunjukan bahwa penggunaan Longissimus dorsi (LD) dengan bahan pengisi $10 \%$ berbeda nyata lebih baik dibandingkan kombinasi perlakuan lainnya, terhadap kadar karbohidrat sosis sapi yaitu 7,76\%. Menurut Sunarlim (1992) semakin sedikit tepung yang ditambahkan mengakibatkan kandungan karbohidrat dalam sosis menjadi rendah sehingga menyebabkan kadar karbohidrat pada kombinasi perlakuan Longissimus dorsi (LD) dengan bahan pengisi 10\% lebih rendah dari kombinasi perlakuan lainnya.

\section{Pengaruh Lokasi Otot terhadap Kualitas Kimia Sosis Sapi}

Pengaruh mandiri lokasi otot (faktor A) terhadap kualitas kimia sosis sapi dapat dilihat pada Tabel 2.

Tabel 2. Rata-rata Pengaruh Mandiri Lokasi Otot pada Kimia Sosis Sapi

\begin{tabular}{lccc}
\hline \multirow{2}{*}{ Peubah } & \multicolumn{3}{c}{ Lokasi Otot } \\
\cline { 2 - 4 } & BF (A1) & LD (A2) & PP (A3) \\
\hline & $13,82 \pm 0,25^{\mathrm{c}}$ & $14,50 \pm 0,25^{\mathrm{b}}$ & $15,79 \pm 0,77^{\mathrm{a}}$ \\
Protein & $19,32 \pm 0,06^{\mathrm{b}}$ & $22,71 \pm 0,39^{\mathrm{a}}$ & $18,45 \pm 0,14^{\mathrm{c}}$ \\
Lemak & $56,37 \pm 0,34^{\mathrm{a}}$ & $53,44 \pm 0,51^{\mathrm{c}}$ & $56,02 \pm 0,18^{\mathrm{b}}$ \\
Air & $2,00 \pm 0,14^{\mathrm{a}}$ & $1,79 \pm 0,03^{\mathrm{b}}$ & $1,75 \pm 0,02^{\mathrm{c}}$ \\
Abu & $8,00 \pm 0,00^{\mathrm{b}}$ & $7,93 \pm 0,17^{\mathrm{c}}$ & $8,01 \pm 0,03^{\mathrm{a}}$ \\
Karbohidrat & \multicolumn{2}{c}{ Notasi huruf yang berbeda ke arah baris menunjukan berbeda sangat nyata pada taraf $(p<0,01)$} \\
\multicolumn{2}{l}{ - Nilai dinyatakan dengan rerata \pm standar deviasi }
\end{tabular}


Kadar Protein sosis sapi berdasarkan lokasi otot, rataan kadar protein tertinggi diperoleh pada A3 (PP) sebesar $15,79 \%$ dan terendah pada A1 (BF) sebesar 13,82\%. Berdasarkan Uji lanjut $\mathrm{BNJ}$ menunjukan protein $\mathrm{PP}$ dan BF nampak adanya perbedaan yang sangat nyata, hal ini sesuai dengan pernyataan (Lawrie, 2003) yang menyatakan bahwa, perbedaan kadar protein daging disebabkan oleh adanya perbedaan struktur dan tingkat aktifitas otot sehingga distribusi nitrogen disetiap otot akan berbeda dan menghasilkan kadar protein daging yang berbeda pula. Lebih lanjut (Muchtadi., dkk, 2010), menyatakan bahwa dengan meningkatnya kandungan lemak daging maka kandungan proteinnya akan menurun.

Berdasarkan Uji lanjut BNJ diperoleh ada perbedaan yang sangat nyata penggunaan Longissimus dorsi (LD) dengan kadar lemak $22,71 \%$ antara penggunaan Biceps femoris (BF) dengan kadar lemak 19,32\% dan Pectoralis profundus (PP) dengan kadar lemak 18, $45 \%$. Hal ini sesuai dengan pernyataan (Soeparno, 2009) yang menyatakan bahwa kadar lemak Longissimus dorsi (LD) lebih tinggi daripada Biceps femoris (BF).

Pada Uji lanjut BNJ menunjukan kadar air BF, LD dan PP berbeda sangat nyata, rataan kadar air tertinggi diperoleh pada perlakuan A1 (BF) sebesar 56,37\% dibandingkan dengan A2 (LD) dan A3 (PP) masing-masing sebesar $(53,44 \%$ dan $56,02 \%)$. Kandungan kadar air sosis yang diperoleh dalam penelitian ini nampaknya sesuai dengan pernyataan

Tabel 3. Rata-rata Pengaruh Mandiri Persen Bahan Pengisi pada Kualitas Kimia Sosis Sapi

\begin{tabular}{lccc}
\hline \multirow{2}{*}{ Peubah } & \multicolumn{3}{c}{ Bahan Pengisi } \\
\cline { 2 - 4 } & $10 \%(\mathrm{~B} 1)$ & $20 \%(\mathrm{~B} 2)$ & $30 \%(\mathrm{~B} 3)$ \\
\hline & $14,93 \pm 0,75^{\mathrm{a}}$ & $14,64 \pm 0,96^{\mathrm{b}}$ & $14,54 \pm 0,89^{\mathrm{c}}$ \\
Protein & $20,41 \pm 2,12^{\mathrm{a}}$ & $20,09 \pm 1,91^{\mathrm{b}}$ & $19,98 \pm 1,81^{\mathrm{c}}$ \\
Lemak & $55,46 \pm 1,20^{\mathrm{a}}$ & $55,52 \pm 1,39^{\mathrm{a}}$ & $54,82 \pm 1,61^{\mathrm{b}}$ \\
Air & $1,90 \pm 0,21^{\mathrm{a}}$ & $1,83 \pm 0,10^{\mathrm{b}}$ & $1,82 \pm 0,05^{\mathrm{c}}$ \\
Abu & $7,92 \pm 0,16^{\mathrm{c}}$ & $8,00 \pm 0,00^{\mathrm{b}}$ & $8,03 \pm 0,03^{\mathrm{a}}$ \\
Karbohidrat & &
\end{tabular}

- Notasi huruf yang berbeda ke arah baris menunjukan berbeda sangat nyata pada taraf $(p<0,01)$

- Nilai dinyatakan dengan rerata \pm standar deviasi 
Uji lanjut BNJ menunjukan protein pada penggunaan bahan pengisi (tepung terigu) $10 \%, 20 \%$ dan $30 \%$ masing-masing berbeda sangat nyata. Rataan kadar protein tertinggi terdapat pada perlakuan B1 $(10 \%)$ yaitu $14,93 \%$ dan terendah terdapat pada perlakuan B3 $(30 \%)$ yaitu $14,54 \%$. Bila dua jenis protein yang memiliki jenis asam amino esensial pembatas yang berbeda diolah bersamasama, maka kekurangan asam amino dari satu protein dapat ditutupi oleh asam amino sejenis yang berlebihan pada protein lain. Dua protein tersebut saling mendukung sehingga mutu gizi campuran menjadi lebih tinggi daripada satu protein (Winarno, 1997).

Uji lanjut BNJ menunjukan bahwa penggunaan bahan pengisi $10 \%$ dengan kadar lemak 20,41\% nyata lebih baik dibandingkan dengan penambahan bahan pengisi $20 \%$ dan $30 \%$ berturut-turut $20,09 \%$ dan 19,98\%. Kadar lemak mengalami penurunan seiring bertambahnya bahan pengisi. Penurunan ini dapat disebabkan kandungan lemak pada tepung terigu sangat rendah. Kenyataan tersebut nampak bahwa, kandungan lemak pada tepung terigu adalah 1,3 g/100g bahan (Depkes, 1996).

Uji lanjut BNJ menunjukan adanya perbedaan yang sangat nyata terhadap kadar air sosis sapi pada setiap bahan pengisi (tepung terigu). Rataan kadar air semakin menurun dengan bertambahnya bahan pengisi berturut-turut B1 (10\%), B2 (20\%) dan B3 (30\%) yaitu $(55,46 \%)$, $(55,52 \%),(54,82 \%)$. Penurunan kadar air terhadap kenaikan bahan pengisi (tepung terigu) disebabkan karena tepung berfungsi sebagai bahan pengikat yang dapat meningkatkan daya ikat air, dimana tepung akan mengikat air yang berada dalam matriks daging sehingga kadar air sosis semakin menurun Manullang dkk, (1995).

Uji lanjut BNJ menunjukan bahwa adanya perbedaan yang sangat nyata disetiap perlakuan. Rataan kadar abu tertinggi diperoleh pada perlakuan
B1(10\%) yaitu $1,90 \%$ dan kadar abu terendah diperoleh pada perlakuan B3 $(30 \%)$ yaitu $1,82 \%$. Kadar abu pada sosis sapi dipengaruhi oleh bahan baku dan bumbu-bumbu lain yang ditambahkan dalam pembuatan sosis tersebut. Kadar abu yang tinggi berarti cukup banyak senyawa kimia dalam bentuk garam atau mineral yang ditambahkan untuk menstabilkan emulsi dan memberikan cita rasa pada sosis sapi (Aberle et al., 2001).

Uji lanjut BNJ menunjukan bahwa bahan pengisi $10 \%$ dengan kadar karbohidrat $7,92 \%$ berbeda nyata lebih baik dibanding penggunaan bahan pengisi $20 \%$ dan $30 \%$ masing-masing (8,0\% dan $8,03 \%)$. Kadar karbohidrat dipengaruhi oleh bahan baku yaitu tepung terigu yang digunakan dan juga kontribusi dari bahanbahan pendukung lainnya seperti susu skim bubuk dan bumbu-bumbu yang ditambahkan dalam formulasi bahan.

\section{B. Kualitas Organoleptik Sosis Sapi}

Hasil analisis ragam menunjukan bahwa, lokasi otot dan bahan pengisi terhadap kualitas organoleptik sosis sapi menunjukan bahwa lokasi otot (faktor A) memberikan pengaruh yang sangat nyata $(p<0,01)$ terhadap warna dan tekstur dan berpengaruh nyata $(p<0,05)$ terhadap keempukan dan aroma tetapi tidak berpengaruh nyata $(p>0,05)$ terhadap citarasa sosis sapi. Sementara bahan pengisi (faktor B) memberikan pengaruh yang sangat nyata $(p<0,01)$ terhadap keempukan dan berpengaruh nyata $(p<0,05)$ terhadap aroma tetapi tidak berpengaruh nyata $(p>0,05)$ terhadap warna, citarasa dan tekstur sosis sapi sedangkan interaksi lokasi otot dan bahan pengisi tetapi tidak berpengaruh nyata $(p>0,05)$ terhadap keempukan, warna, citarasa, aroma dan tekstur.

\section{Pengaruh Interaksi Lokasi Otot dengan Bahan Pengisi}

Rataan interaksi skor penilaian panelis terhadap kualitas organoleptik sosis sapi dapat dlihat pada Tabel 4. 
Tabel 4. Rata-rata Interaksi Skor Penilaian Panelis Penggunaan Lokasi otot dan Bahan Pengisi terhadap Kualitas Organoleptik Sosis Sapi

\begin{tabular}{|c|c|c|c|c|}
\hline \multirow{2}{*}{ Peubah } & \multirow{2}{*}{ Lokasi Otot } & \multicolumn{3}{|c|}{ Bahan Pengisi } \\
\hline & & $10 \%(\mathrm{~B} 1)$ & $20 \%(\mathrm{~B} 2)$ & $30 \%(\mathrm{~B} 3)$ \\
\hline & & \multicolumn{3}{|c|}{ 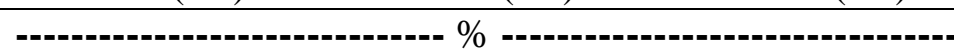 } \\
\hline \multirow{3}{*}{ Keempukan } & $\mathrm{BF}(\mathrm{A} 1)$ & $3,00 \pm 0,00$ & $3,33 \pm 0,13$ & $3,03 \pm 0,17$ \\
\hline & $\mathrm{LD}(\mathrm{A} 2)$ & $3,40 \pm 0,00$ & $3,33 \pm 0,13$ & $3,06 \pm 0,26$ \\
\hline & $\mathrm{PP}(\mathrm{A} 3)$ & $3,13 \pm 0,07$ & $3,23 \pm 0,17$ & $2,79 \pm 0,13$ \\
\hline \multirow{3}{*}{ Warna } & $\mathrm{BF}(\mathrm{A} 1)$ & $2,96 \pm 0,10$ & $2,93 \pm 0,00$ & $2,79 \pm 0,13$ \\
\hline & $\mathrm{LD}(\mathrm{A} 2)$ & $3,33 \pm 0,00$ & $3,19 \pm 0,13$ & $3,20 \pm 0,20$ \\
\hline & PP (A3) & $3,26 \pm 0,20$ & $3,13 \pm 0,26$ & $3,16 \pm 0,23$ \\
\hline \multirow{3}{*}{ Aroma } & $\mathrm{BF}(\mathrm{A} 1)$ & $3,10 \pm 0,30$ & $3,26 \pm 0,06$ & $3,03 \pm 0,10$ \\
\hline & $\mathrm{LD}(\mathrm{A} 2)$ & $3,33 \pm 0,06$ & $3,33 \pm 0,00$ & $3,29 \pm 0,03$ \\
\hline & PP (A3) & $3,26 \pm 0,13$ & $3,30 \pm 0,10$ & $3,06 \pm 0,13$ \\
\hline \multirow{3}{*}{ Citarasa } & $\mathrm{BF}(\mathrm{A} 1)$ & $2,59 \pm 0,46$ & $2,70 \pm 0,30$ & $2,96 \pm 0,16$ \\
\hline & $\mathrm{LD}(\mathrm{A} 2)$ & $2,96 \pm 0,10$ & $2,86 \pm 0,00$ & $2,83 \pm 0,16$ \\
\hline & PP (A3) & $3,16 \pm 0,10$ & $3,06 \pm 0,20$ & $2,73 \pm 0,07$ \\
\hline \multirow{3}{*}{ Tekstur } & $\mathrm{BF}(\mathrm{A} 1)$ & $2,39 \pm 0,06$ & $3,60 \pm 0,07$ & $3,46 \pm 0,46$ \\
\hline & $\mathrm{LD}(\mathrm{A} 2)$ & $3,53 \pm 0,33$ & $2,63 \pm 0,10$ & $2,36 \pm 0,30$ \\
\hline & PP (A3) & $3,63 \pm 0,17$ & $3,43 \pm 0,30$ & $3,46 \pm 0,33$ \\
\hline
\end{tabular}

menunjukan bahwa interaksi lokasi otot dan bahan pengisi tidak berpengaruh nyata $(p>0,05) \quad$ terhadap semua parameter kualitas organoleptik sosis sapi. Secara umum rataan skor penilaian panelis
2,36 - 3,63 yaitu cukup suka sampai suka.

2. Pengaruh Lokasi Otot terhadap Kualitas Organoleptik Sosis Sapi

Pengaruh mandiri lokasi otot (faktor A) terhadap kualitas organoleptik sosis sapi dapat dilihat pada Tabel 5.

Tabel 5. Rata-rata Skor Penilaian Panelis Pengaruh Mandiri Lokasi otot terhadap Kualitas Organoleptik Sosis Sapi.

\begin{tabular}{lccc}
\hline \multirow{2}{*}{ Peubah } & \multicolumn{3}{c}{ Lokasi Otot } \\
\cline { 2 - 4 } Keempukan & BF (A1) & LD (A2) & PP (A3) \\
\hline Warna & $3,12 \pm 0,19^{\text {ab }}$ & $3,26 \pm 0,21^{\mathrm{a}}$ & $3,05 \pm 0,22^{\mathrm{b}}$ \\
Aroma & $2,89 \pm 0,11^{\mathrm{b}}$ & $3,24 \pm 0,13^{\mathrm{a}}$ & $3,18 \pm 0,21^{\mathrm{ab}}$ \\
Citarasa & $3,13 \pm 0,19^{\mathrm{b}}$ & $3,32 \pm 0,04^{\mathrm{ab}}$ & $3,20 \pm 0,15^{\mathrm{a}}$ \\
Tekstur & $2,75 \pm 0,33$ & $2,88 \pm 0,11$ & $2,98 \pm 0,22$ \\
\hline
\end{tabular}

- Notasi huruf yang berbeda ke arah baris menunjukan berbeda sangat nyata pada taraf $(p<0,01)$

- Nilai dinyatakan dengan rerata \pm standar deviasi Berdasarkan uji lanjut BNJ menunjukan bahwa keempukan sosis sapi pada LD (A2) dengan skor 3,26 (empuk) lebih empuk dibandingkan BF dengan skor 3,12 dan PP dengan skor 3,05. Keempukan sosis sapi terbentuk ketika molekulmolekul protein mengembang sewaktu pengukusan. Gugus reaktif rantai polipetida terbuka, selanjutnya terjadi pengikatan kembali pada gugus reaktif yang sama atau berdekatan. Banyaknya ikatan yang terbentuk menyebabkan protein tidak lagi terdispersi sebagai koloid melainkan mengalami koagulasi. Ikatanikatan antara gugus reaktif protein menahan seluruh cairan yang membentuk gel, sehingga membentuk keempukan sosis sapi (Winarno, 1997).

Uji lanjut BNJ menunjukan bahwa warna sosis sapi pada perlakuan A2 (LD) yaitu 3,24 (merah kecoklatan) lebih disukai dibandingkan A1 (BF) dengan skor 
2,89 (kecoklatan) dan A3(PP) dengan skor 3,05 (kecoklatan). Menurut Kramlich, et al., (1982), menyatakan bahwa pigmen yang berperan pada daging yang tidak dimasak adalah pigmen oksimioglobin yang akan memberi warna merah cerah. Pada daging yang dimasak pigmen yang berperan adalah globin hemikromagen, yang memberikan warna merah kecoklatan. Warna daging sapi lebih ditentukan oleh pigmen daging yang terbentuk selama pemasakan yaitu globin hemikromagen. Aroma sosis sapi berdasarkan uji lanjut BNJ menunjukan bahwa perlakuan A2 (LD) dengan skor 3,32 (disukai) lebih disukai dibandingkan perlakuan A3 (PP) dengan skor 3,20 dan perlakuan $\mathrm{A} 1(\mathrm{BF})$ yaitu 3,13. Aroma dipengaruhi oleh penambahan bumbubumbu yaitu merica, bawang putih dan pala pada pembuatan sosis (Soeparno, 2009).
Uji BNJ menunjukan bahwa tekstur pada perlakuan A2(LD) dengan skor 3,53 (halus) lebih halus dibandingkan A3 (PP) 3,50 dan A1 (BF) dengan skor 2,46. Faktor-faktor yang mempengaruhi tekstur bahan pangan adalah jenis protein, suhu pengolahan dan kadar air (Kramlich et.al., 1982). Protein dari daging mempunyai kemampuan untuk mengikat lemak dan air dimana protein tersebut akan menyelubungi lemak yang terdapat pada sosis sehingga emulsi sosis lebih stabil dan tekstur lebih padat dan empuk. Selain itu menurut Buckle, et al., (1987), menyatakan penambahan bahan pengikat (susu skim) adalah bahan bukan daging yang bertujuan memperbaiki elastisitas dari produk akhir.

\section{Pengaruh Bahan Pengisi terhadap Kualitas Organoleptik Sosis Sapi \\ Pengaruh mandiri bahan pengisi pada kualitas organoleptik sosis sapi dapat dilihat pada Tabel 6 .}

Tabel 6. Rata-rata Skor Penilaian Panelis Pengaruh Mandiri Bahan Pengisi terhadap Kualitas Organoleptik Sosis Sapi

\begin{tabular}{|c|c|c|c|}
\hline \multirow{2}{*}{ Peubah } & \multicolumn{3}{|c|}{ Bahan Pengisi } \\
\hline & $10 \%(\mathrm{~B} 1)$ & $20 \%(\mathrm{~B} 2)$ & $30 \%$ (B3) \\
\hline & --------------------.. & --. \% --------. & --------------.. \\
\hline Keempukan & $3,29 \pm 0,13^{\mathrm{a}}$ & $3,17 \pm 0,18^{\mathrm{ab}}$ & $2,96 \pm 0,21^{\mathrm{b}}$ \\
\hline Warna & $3,18 \pm 0,20$ & $3,08 \pm 0,19$ & $3,05 \pm 0,25$ \\
\hline Aroma & $3,23 \pm 0,19^{\mathrm{ab}}$ & $3,29 \pm 0,06^{\mathrm{a}}$ & $3,13 \pm 0,15^{\mathrm{b}}$ \\
\hline Citarasa & $2,90 \pm 0,34$ & $2,87 \pm 0,23$ & $2,84 \pm 0,15$ \\
\hline Tekstur & $3,18 \pm 0,62$ & $3,22 \pm 0,47$ & $3,09 \pm 0,63$ \\
\hline
\end{tabular}

- Notasi huruf yang berbeda ke arah baris menunjukan berbeda sangat nyata pada taraf $(p<0,01)$

- Nilai dinyatakan dengan rerata \pm standar deviasi

Berdasarkan uji lanjut BNJ menunjukan bahwa keempukan sosis sapi pada bahan pengisi (tepung terigu) $10 \%$ dengan skor 3,29 lebih empuk dibandingkan dengan perlakuan B2 $(20 \%)$ yaitu 3,17 dan perlakuan B3 (30\%) dengan skor 2,96. Hal ini disebabkan bahan pengisi yang digunakan lebih sedikit dibandingkan dengan perlakuan lainnya, kadar air pada bahan pengisi $10 \%$ lebih tinggi sehingga dapat meningkatkan keempukan sosis sapi.
Aroma sosis sapi berdasarkan uji lanjut BNJ menunjukan bahwa perlakuan B2 (20\%) yaitu 3,29 (disukai) lebih disukai dibandingkan perlakuan A1 (10\%) dengaan skor 3,23 dan perlakuan A3 (30\%) yaitu 3,13. Aroma sosis dipengaruhi oleh beberapa faktor sebagai suatu kesatuan yang utuh, antara lain bumbubumbu dan daging. Menurut Kartika, dkk (1988), aroma sosis yang dihasilkan terutama disebabkan oleh bumbu-bumbu yang digunakan selama prosesing yaitu merica, bawang putih dan pala sehingga menimbulkan aroma yang khas. 


\section{KESIMPULAN}

Dari hasil penelitian sosis sapi yang menggunakan lokasi otot dan bahan pengisi maka dapat disimpulkan 1) berdasarkan kualitas kimia interaksi lokasi otot dan bahan pengisi yang baik untuk pembuatan sosis sapi yaitu PP (Pectoralis profundus) dengan bahan pengisi $10 \%$ dilihat dari kadar lemak yang rendah dan protein yang tinggi sedangkan berdasarkan kualitas organoleptik yaitu LD (Longissimus dorsi) dengan bahan pengisi $10 \%$ dilihat dari tingkat kesukaan panelis dan penampakan umum.2) Lokasi otot secara mandiri berpengaruh sangat nyata terhadap protein, lemak, kadar air, kadar abu, warna, tekstur dan berpengaruh nyata terhadap kadar karbohidrat, keempukan dan aroma sosis sapi. 3) Bahan pengisi secara mandiri berpengaruh sangat nyata terhadap protein, lemak, kadar air, kadar abu, keempukan dan berpengaruh nyata terhadap kadar karbohidrat dan aroma sosis sapi.

\section{DAFTAR PUSTAKA}

Aberle, E. D., J. C. Forrest, D. E. Gerrard, E. W. Mills, H. B. Hedrick, M. D. Judge dan R. A. Markel. 2001. Pronciples of Meat Science. 4thEdition. Kendall/Hutt Publishing Co, Iowa.

Buckle K.A., Erwards R. A, Fleet G. H, dan Wootton M, 1987. Ilmu Pangan. Terjemahan Hari Purnomo dan Adino. Universitas Indonesia Press. Jakarta.

Departemen Kesehatan RI . 1996. Karkas dan Bagian bagiannya. Universitas Sumatera Utara. http://repository.usu.ac.id/Chapter\% 20II.pdf[14september 2011].

Effendi, S. 2009. Teknologi Pengolahan dan Pengawetan Pangan. Alfabeta CV. Bandung.

Kartika, B. 1988. Uji mutu pangan. Pusat antar Universitas pangan dan gizi. UGM. Yogyakarta.
Kramlich, R. V. 1982. Sausage product. Dalam: J. F. Prince dan B.S. Schweigert (Editor). The Science of Meat and Meat Product. W.H. Freeman and Company, San Fransisco. Poultry and Seafood Technology. Prentice Hall Inc.

Maharaja, L. M., 2008. Penggunaan campuran tepung tapioka dengan tepung sagu dan natrium nitrat dalam pembuatan bakso daging sapi. Skripsi Fakultas Pertanian, Universitas Sumatera Utara. Sumatera Utara. (online) http://repository.usu.ac.id/bitstream/ 123456789/7527/.pdf.

[10 September 2011].

Manullang, M, M. Theresia dan H.E Irianto., 1955. Pengaruh konsentrasi tepung terigu dan sodiumtrifosfat terhadap mutu dan daya awet sosis. Buletin Teknologi dan ilmu pangan. 6 (2): 21-26.

Muchtadi., T.R., Sugiyono, Ayustaningwarno, F. 2010. Ilmu Pengetahuan Bahan Pangan. Alfabeta CV. Bandung.

Steel, R.G.D., dan Torrie, J.H., 1991. Prinsip dan Prosedur Statistik Suatu Pendekatan Biometrik. Terjemahan: Sumantri, B. Gramedia Pustaka Utama. Jakarta.

Soeparno. 2009. Ilmu dan Teknologi Daging. Gadjah Mada University Press. Yogyakarta.

Sunarlim, R., 1992. Karakteristik Mutu Fisik Bakso Daging Sapi dan Pengaruh Penambahan Natrium Klorida dan Natrium Trifosfat Terhadap Perbaikan Mutu. Disertasi. Program Pascasarjana IPB. Bogor.

Winarno, F.G. 1997. Kimia Pangan dan Gizi. PT Gramedia. Jakarta. 